\title{
Archeological Testing at the Prehistoric Site of 41SM231 Smith County, Texas
}

Steven Ahr

Follow this and additional works at: https://scholarworks.sfasu.edu/ita

Part of the American Material Culture Commons, Archaeological Anthropology Commons, Environmental Studies Commons, Other American Studies Commons, Other Arts and Humanities Commons, Other History of Art, Architecture, and Archaeology Commons, and the United States History Commons

Tell us how this article helped you.

This Article is brought to you for free and open access by the Center for Regional Heritage Research at SFA ScholarWorks. It has been accepted for inclusion in Index of Texas Archaeology: Open Access Gray Literature from the Lone Star State by an authorized editor of SFA ScholarWorks. For more information, please contact cdsscholarworks@sfasu.edu. 


\section{Archeological Testing at the Prehistoric Site of 41SM231 Smith County, Texas}

\section{Licensing Statement}

This is a work produced for the Texas Department of Transportation (TxDOT) by the report producer. TxDOT and the report producer jointly own all rights, title, and interest in and to all intellectual property developed under TXDOT's contract with the report producer. The report may be cited and brief passages from this publication may be reproduced without permission provided that credit is given to both TxDOT and the report producer. Permission to reprint an entire chapter, section, figures or tables must be obtained in advance from either the Supervisor of the Archeological Studies Branch, Environmental Affairs Division, Texas Department of Transportation, 125 East 11th Street, Austin, Texas, 78701 or from the report producer. 


\title{
ARCHEOLOGICAL TESTING at the PREHISTORIC SITE of 41SM231 SMITH COUNTY, TEXAS
}

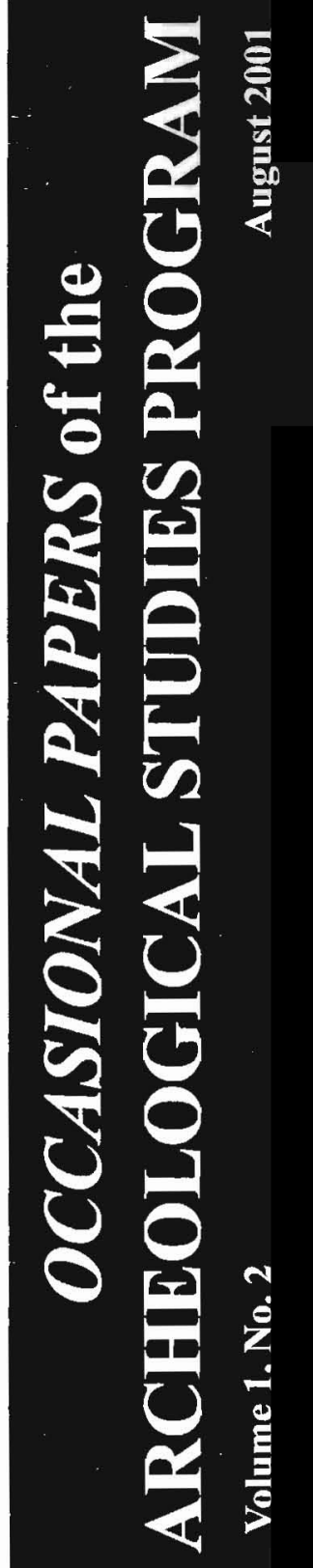

\author{
by Steven Ahr
}

TEXAS DEPARTMENT OF TRANSPORTATION ENVIRONMENTAL AFFAIRS DIVISION 


\section{ARCHEOLOGICALTESTING at the PREHISTORIC SITE of 41SM231, SMITH COUNTY, TEXAS}

\section{Occasional Papers of the Archeological Studies Program \\ Volume 1, No. 2}

Copyright 2001 by the Texas Department of Transportation (TxDOT)

All rights reserved.

Published by the Texas Department of Transportation

August 2001 Austin, Texas

on acid-free paper

For further information on this and other TXDOT archeological publications

please contact:

Texas Department of Transportation

Environmental Affairs Division

Archeological Studies Program

Nancy A. Kenmotsu, Ph.D., Supervisor

Archeological Studies Program Reports

A. McGraw, Editor

Production of this report was directed by

Timothy Meade

About the cover: The design on a prehistoric ceramic sherd found at 41SM231 is similar to that of previously found pottery vessels in East Texas. Cover design by Henry Gregory Quinn. 


\section{ARCHEOLOGICAL TESTING at the PREHISTORIC SITE of 41SM231, SMITH COUNTY, TEXAS}

Occasional Papers of the Archeological Studies Program

Volume 1, No. 2

Steven Ahr

August 2001 

to maximize federal funding for highways, public transportation, and aviation purposes, and to help the Department achieve its performance measures set out in the General Appropriations Act, H.B.I, 76th Legislature, Regular Session. This publication has been filed with the State Publications Clearinghouse in the State Library in accordance with the Texas State Depository Law. 


\section{MANAGEMENT SUMMARY}

In December 1998, TxDOT archeologists conducted an archeological survey for the proposed expansion of the walking and bicycle facility at Rose Rudman Park in Tyler, Texas. One previously unrecorded archeological site (41SM231) was recorded within the ca. 10-m wide trail corridor. In March 1999, TxDOT archeologists excavated two contiguous 1-x-1-m test units at the site. Ninety-eight aboriginal ceramic sherds were recovered from test units and shovel tests. Recovered lithics include only a single edge-modified flake and a few pieces of debitage. No burned rock features, feature stains, postmolds, or datable remains were identified.

One Canton Incised and two Poyner Engraved sherds were recovered that suggest that the site was occupied between the Early to Late Caddoan Periods (AD 1000 to 1600). Most of the recovered sherds were small ( $<2 \mathrm{~cm}$ diameter), without any diagnostic features. Fieldwork indicated that the upper ca. $50 \mathrm{~cm}$ of deposits was impacted and reworked by a variety of site formation processes. Most of the ceramics have been broken to a point beyond our ability to gain useful typologically grounded information about the aboriginal inhabitants of this region. Given the small number of artifacts and their generally small size, it is unlikely that this assemblage could yield important new information.

The portion of 41SM231 within the trail corridor does not retain sufficient integrity nor is it likely to yield important information that would make it eligible for inclusion in the National Register of Historic Places (NRHP) or merit designation as a State Archeological Landmark (SAL). Therefore, construction of the proposed trail should have no effect on archeological historic properties or SALs, and no further archeological work is recommended. However, because the site may extend beyond the examined corridor, future development activity adjacent to the trail may require examination to determine whether intact archeological deposits are present. 



\section{TABLE OF CONTENTS}

MANAGEMENT SUMMARY

TABLE OF CONTENTS . iii

LIST OF FIGURES ii

LIST OF TABLES .$i 1$

ACKNOWLEDGMENTS iv

INTRODUCTION 1

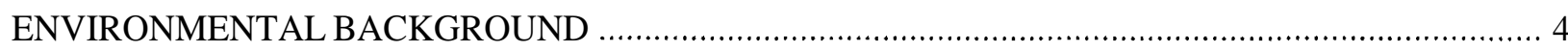

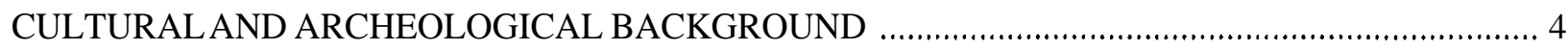

ARCHEOLOGICA L SURVEY OF PROPOSED TRAILS ........................................................ 7

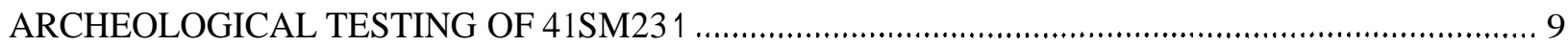



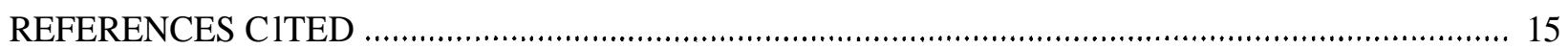

\section{LIST OF FIGURES}

Figure 1. Project area. Texas Department of Transportation map \#212. Smith County ......................... 2

Figure 2. Map showing trail locations. shovel tests. and newly recorded site 41SM23 1 ....................... 3

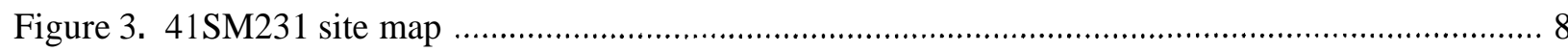

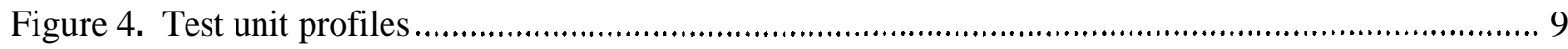

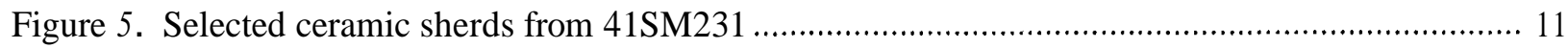



\section{LIST OF TABLES}

Table 1. Summary of cultural chronology in Northeast Texas (data compiled from Fields et al. 1993. Perttula 1988; Perttula and Kenmotsu 1993; Perttula et al. 1993; Story 1990) ........................... 5

Table 2. Distribution of archeological materials by level ............................................................ 10

Table 3. Distribution of ceramic attributes by level ................................................................ 13 


\section{ACKNOWLEDGMENTS}

Several individuals contributed to this project. Jay Tullos, Lance Marshall, and Christine Crosby from the Tyler District of the Texas Department of Transportation coordinated this project at the local level. They also participated in the fieldwork during survey and excavation. From ENV, archeologist Patrick McLoughlin helped during the excavation phase, and provided comments on earlier drafts of this report. Jesus "Chuy" Gonzalez from ENV helped in the laboratory processing of the recovered artifacts, and Dennis Price provided much assistance in identifying ceramic types and providing references. Nancy Kenmotsu, Archeological Studies Branch Supervisor, provided guidance throughout the project, and was particularly helpful during the ceramic analysis. She and Lain Ellis, made valuable comments on earlier drafts of this report. To all these individuals, and any that may have been inadvertently omitted, I offer my sincere thanks. 


\section{INTRODUCTION}

The Tyler District of the Texas Department of Transportation proposes to augment the park trail system at Rose Rudman Park within the city of Tyler by expanding the existing walking and bicycle facility. The project area is an undeveloped wooded tract bordered by Copeland Road to the east, South Donnybrook Avenue on the west, Shiloh Road on the south and an office complex on the north.

In December 1998 TxDOT archeologist Steve Ahr conducted an archeological survey of the proposed route. He located a previously unrecorded archeological site (41SM231) buried in loose, sandy sediments. Several ceramic sherds were recovered. In March 1999 TxDOT archeologists Steve Ahr and Pat McLoughlin, with the assistance of Jay Tullos, Christine Crosby, and Lance Marshall from the Tyler District, excavated two I-x-1-m test units. The purpose of these investigations was to assess the integrity of the portion of the site within the area of potential effect and determine whether or not that portion could contribute to the site's eligibility.

\section{Project Description}

The project area is located at Rose Rudman Park about 500 m south of Loop 323 in Tyler (Figure 1). It is situated upon a relatively flat area between two tributaries of Mud Creek. The land is currently used for recreation as a wooded walking trail. The surrounding area is urbanized.

Currently, there is a paved east-west trail at the north end of the project area (Figure 2). This paved trail crosses the west branch tributary of Mud Creek then turns south following the creek. On the east side of the creek there is an unpaved footpath that connects the existing paved trail at the north end to the existing trail system to the south. The current project will add two paved trail segments. The proposed west trail will pave the footpath. The proposed east trail will wind northeast through the wooded portion of the project area and connect with the existing north trail near the eastern terminus.

The trail will be constructed as a series of 10 ftwide, 4 inch-thick concrete sections and will total approximately 0.52 miles in length. A $30-\mathrm{ft}$ ( $9.12 \mathrm{~m})$ corridor will be cleared the length of the trail to allow equipment access. The total estimated area of the trail corridor is approximately 1.88 acres. The proposed trail will follow natural ground contours, and no cuts are required. Small diameter piping will convey cross drainage below the trail where necessary. At these locations, the pipe will be laid within existing channels and covered with trail material. In order to preserve the natural setting, the trail enhancement will be constructed so as to minimize impacts to trees.

Other aspects of the project include the installation of a temporary construction entrance on the north end of the trail system. A rock filter dam will also be constructed on the east edge of the project downstream of thestorm sewer to trap sediment from construction. Other silt fences will be located along the project for the same purpose. Since the city of Tyler owns the property on which the trail will be constructed, no new right-of-way will be needed. 
This Page Redacted Per THC Policy 


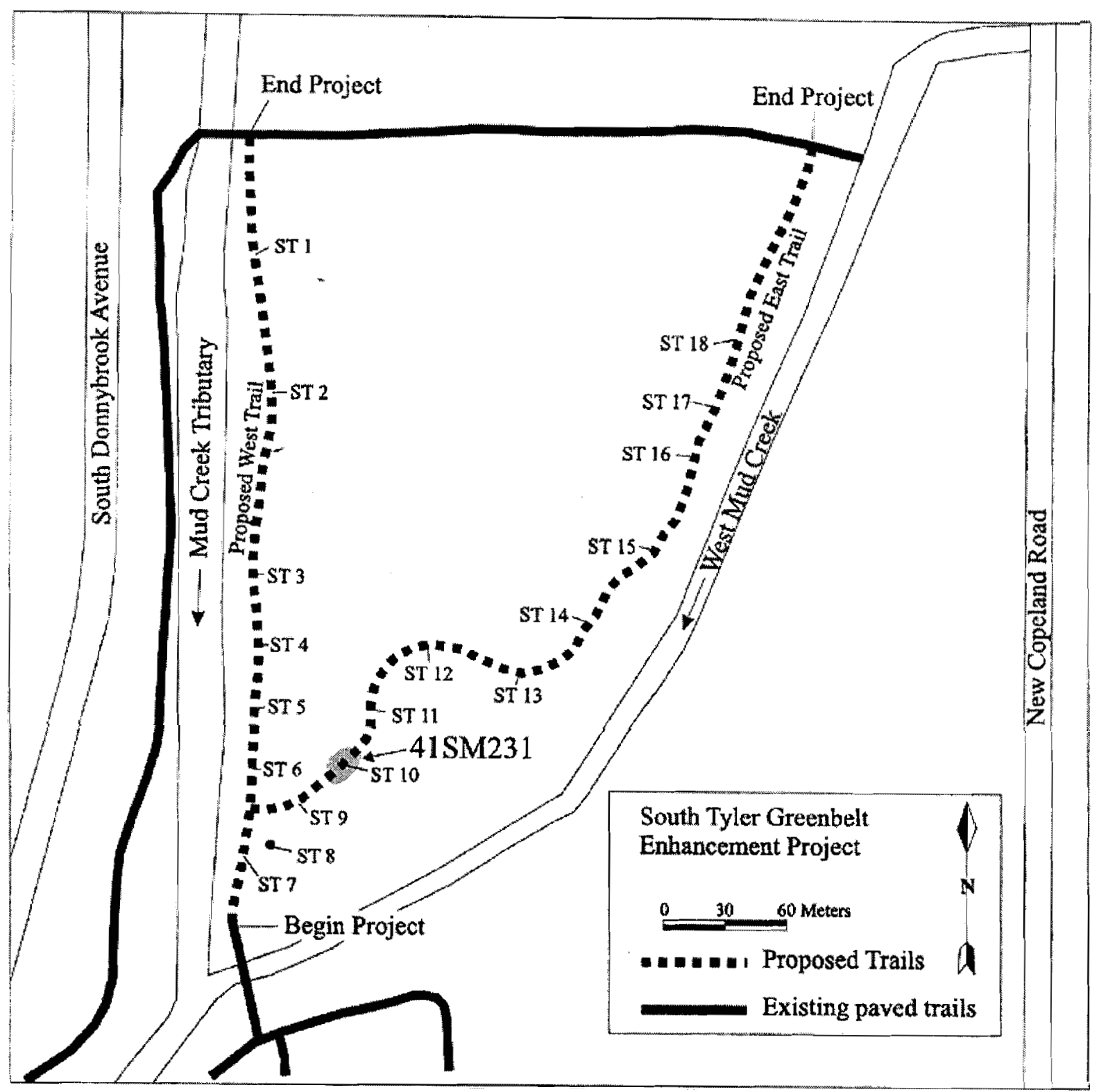

Figure 2. Map showing trail locations, shovel tests, and newly recorded site 41SM231. 


\section{ENVIRONMENTAL BACKGROUND}

\section{Ecological Setting}

The project area is located within the Gulf Coastal Plain Physiographic Province near the convergence of the Post Oak Savannah and Pine Hardwood forest (Fenneman 193 1; Gould 1975). The project area also lies within the Austroriparian Biotic Province as defined by Blair (1950). The Pineywoods area is characterized by moderately dense woodland, such as Sweetgum, Sassafras, Red and White Oaks, and Loblolly Pine. Vegetation also includes various grasses such as smutgrass, broomsedge bluestem, and red lovegrass. Post Oak Savannah vegetation is characterized by mixed prairie and woodland. Woodland is dominated by post oak, blackjack oak, and eastern juniper and common grasses include little bluestem, lndiangrass, and switchgrass (Gould 1975). The current tract is undeveloped and is typified by east Texas forest overstory such as sweetgum, American Elm, water oak, laurel oak, sycamore, black willow, and cottonwood.

\section{Hydrology}

Tyler is situated within the Neches-Angelina River basin. The project area is located just east of the Neches and Angelina upland divide about 9 miles east of the Neches River. The proposed trail route lies between two tributary branches of West Mud Creek. Each of these drainages is relatively narrow (approximately $5 \mathrm{~m}$. across), and has downcut approximately 3 to 4 meters into mostly upland Tertiary deposits. These branches form West Mud Creek, which runs southeast through Smith County and joins Mud Creek near Troup, Texas on the Smith/Cherokee County line. Mud Creek continues south and southeast through Cherokee County and enters the Angelina River around Reklaw near the Rusk County line.

Both branches have been extensively channelized in the past to improve city drainage and minimize overbank flooding. Several minor drainage features cross the interfluvial area. These small, unconfined stream channels are typically about 0.4 meters in depth and 3-5 meters across, and convey upland drainage and surface runoff. They were dry during the first visit in December 1998. However, during fieldwork conducted March 1999, a small drainage near the site contained between 30 and $40 \mathrm{~cm}$ of stagnant water.

\section{Geology and Soils}

The majority of the tract consists of a thin sandy soil developed on the sandy clay Sparta Sands formation (Es). This formation is comprised of quartz and sand. The sand is fine- to medium- grained, light gray to brownish gray, massive, and contains interbeds of sandy clay and inclusions of ironstone concretions (Barnes 1967). Within most of the project area, it appears that the majority of upland sandy mantel deposits had been eroded down to the sandy clay subsoil, although a few sandy areas were observed throughout the trail.

Mapped soils in the project area include DerlyBesner complex (Db), Oakwood fine sandy loam (OkB), Wolfpen loamy fine sand (WoC), Cuthbert fine sandy loam, Elrose fine sandy loam (ErB), $\mathrm{KgC} \mathrm{Kirvin} \mathrm{gravelly} \mathrm{fine} \mathrm{sandy} \mathrm{loam,} \mathrm{and} \mathrm{Sacul}$ very fine sandy loam $(\mathrm{SaC}$ ) (Soil Survey, Smith County, Texas). These soils are typically well drained to moderately well drained, and textures range from clayey subsoil to fine sandy loam and very fine sandy loam. These soils are characterized by gently sloping to strongly sloping on uplands and inter-stream divides on uplands. Within the Mud Creek floodplain, soils are classified as Kirvin very fine sandy loam (KfC). The area immediately adjacent to the channels of Mud Creek area classified as Mantachie Loam (Ma), which is hydric in Smith County.

\section{CULTURAL AND ARCHEOLOGICAL BACKGROUND}

\section{Cultural Background}

A generalized cultural-chronologic framework of Northeast Texas is provided here to view the project area within a broader cultural and archeological context. In general, the prehistoric cul- 
tural trend has been a move from highly mobile hunter-gatherers to increased sedentism, and the development of agriculture and complex societies. While prehistoric peoples ostensibly occupied this region for the last 9,000-10,000 years, this section focuses mainly on the Caddoan cultural development in the region based on the archeological record. Table 1 summarizes the major aspects of the cultural periods prior to the Caddoan period.

The project area is located in the Neches-A ngelina drainage basin within the Caddoan archeological area (Perttula 1992). This area, commonly referred to as the Trans-Mississippi South (Perttula and Bruseth 1998:1), encompasses portions of Texas, Louisiana, Arkansas, and Oklahoma. The Caddo occupied this region from around AD 800 until the recent historic period AD 1860. This period is marked by reliance on cultigens such as corn, the development of many utilitarian and stylistic ceramics, and settled residences (e.g., hamlets and villages). Much of this, including ranked societies, civic-ceremonial centers such as multiple and single mound complexes, elaborate mortuary practices, and extensive trade networks, has been identified archeologically (Perttula and Bruseth
1998:2).The archeological expression of Caddoan culture is divided chronologically into the Formative Caddoan (AD 800-1000). Early Caddoan (AD 1000-1200), Middle Caddoan (AD 1200-1400), Late Caddoan (AD 1400-1680), and Historic Caddoan (AD 1680-1860) (see Story 1990).

Site patterning within the Neches-Angelina basin likely follows the same broad patterns outlined by Thurmond (1990) for the Cypress Creek drainage basin. Most Caddoan sites tend to occur in a valley setting, particularly along floodplain floors, floodplain rises, terraces, and upland slopes and projections. Settlements also co-occur frequently with natural springs. Nearly 5,000 recorded sites in Northeast Texas can be assigned to the Caddoan archeological tradition (Perttula 1993a:124). Common site types for this period include ceremonial mound centers, cemeteries, villages, hamlets, and farmsteads.

The Neches-AngelinaRiver Basin contains numerous and important archeological deposits relating to the various stages of Caddoan cultural development. Smith County, as with most counties in the Eastern Planning Region of Texas (see Perttula and Kenmotsu 1993),contains significantCaddoan

Table 1. Summary of cultural chronology in Northeast Texas (data compiled from Fields et al. 1993, Perttula 1988; Perttula and Kenmotsu 1993; Perttula et al. 1993; Story 1993).

\section{Period \\ Paleo-Indian $9500 \mathrm{BC}-7000 \mathrm{BC}$}

\author{
Archaic \\ 7000 BC - 200 BC
}

\section{Early Ceramic 200 BC - AD 800}

\section{Characteristics}

Diagnostics: Clovis, Folsom, Dalton. San Patrice, Scottsbluff projectile points. Cultural characteristics: Small mobile hunter-gatherer groups. Few sites in NE Texas; most are ephemeral. Occupation debris sparse; paucity of middens and house remains. Use of exotic raw materials.

Site characteristics: Located on upland stable and/or eroded surfaces. Subsistence: Reliance on large game animals.

Diagnostics: Early Gary dart points; Clear Fork tools.

Cultural characteristics: Hunter-gatherers with decrease in territory size/restricted mobility; increased population. Less reliance on exotic materials; greater use of localized lithic sources.

Site characteristics: Located on wide range of topographic and geomorphic settings. Sites typically dominated by lithic assemblages. Larger accumulations of refuse. Subsistence: Greater reliance on plant remains. Hardwood nut shells at sites and burned rock concentrations are common.

Diagnosties: Later Gary dart points, expanded stem arrow points, sandy paste/grogtempered wares: Williams Plain, Cooper Boneware, Marksville, and Troyville ceramics. Possibly related to Fourche Maline culture.

Cultural characteristies: Burial mounds: Increasing group size; Increased sedentism/complexity.

Site characteristics: Small and ephemeral sites, although some are fairly large and complex (e.g., Hurricane Hill; see Perttula [1988]).

Subsistence: Development of agriculture, manufacture of pottery, use of bow and arrow. Reliance on plant gathering and hunting. 
sites, and is particularly abundant in sites from the Formative to Middle Caddoan periods (Perttula 1993a:125). Just west of Tylerat what is now Lake Palestine (previously Blackburn Crossing Reservoir), previous archeological excavations were carried out by LeRoy Johnson, Jr. and W.A. Davis in 1957 and the East Texas Archeological Society (Guy 1990:57), the Texas Archaeological Salvage project (Story 1965; Johnson 1961), and Southern Methodist University (Anderson 1972). Many of the sites investigated were attributed to the Late Caddoan Frankston Focus, although at least one Early Caddoan Alto focus component was identified. This focus was previously defined from investigations at the George C. Davis Site, located south of the project area in Cherokee County in the Neches drainage basin (Guy 1990:57). The George C. Davis Site on the middle Neches River, as well as the Washington Square Site and Pace McDonald Site, are the only multiple mound center sites in the Neches-Angelina River basins (see Perttula 1993a:130; Story 1990, 1997). Single mound centers are infrequently recorded within these limits, although Smith County contains three in the northern part of the county, along with a multiple mound site, and one single mound site in the southwest portion adjacent to Lake Palestine.

The upper Neches River Basin is well represented by Late Caddo sites that tend to cluster as small intact, dispersed settlements with associated cemeteries. The mounds constructed during this period were typically associated with these smaller settlements, although they are smaller and fewer in number from mounds of the Early Caddoan period (Perttula 1993a:123-128). Similar archeological manifestations are found throughout the Angelina River Basin, but occur in somewhat smaller clusters (Perttula 1993a:126-127). These clusters likely were focal points for social and ceremonial gatherings whereby mound sites served a variety of mortuary, ceremonial, political, and civic purposes. Presumably, these changes in site structure were also reflective in ceremonial practices.

Around the project area Late Caddoan sites are usually associated with either the Angelina focus or Frankston focus. Archeological survey by SMU prior to the enlargement of Lake Palestine from
1969-1970 identified 85 sites, most of which were attributed to the Late Caddoan Frankston focus (Guy 1990:92). Consistent with previous investigations, a few Early Caddoan Alto Focus sites were also recorded. Excavations were carried out by SMU at 10 of these sites (see Anderson et al. 1974; Gilmore 1983). focusing mainly on habitation areas, revealing Alto focus components at three sites and Frankston focus components at all sites (Guy 1990:92). South of the Sabine River within the Neches-Angelina basin, Smith County is one of several counties that contain a large number of Caddoan cemeteries (Perttula 1993a:127). Nearby in along the banks of Lake Palestine, Texas A\&M University carried out excavations at the Attaway site (see Shafer 1981), revealing a Frankston focus cemetery and midden deposits (Guy 1990:92).

During the historic period the Caddo subsisted on corn agriculture, native fauna, and native flora while living in dispersed villages or hamlets (Perttula and Kenmotsu 1993:47). The southern Caddos were known as the Hasinai and Caddos to the north were known as the Kadohadacho. A Protohistoric Caddoan Period (AD 1540-1680) is coeval with the terminal Late Caddoan Period (see Story 1990), and corresponds to about the time of sporadic historic contact with European explorers (Perttula 1993b:148). As previously stated the Neches River basin is one of a few areas where Late Caddoan farmsteads and hamlets clustered, with smaller sized clusters in the Angelina basin. The Deshazo Site, located south of theproject area in the Middle Angelina drainage basin in Nacogdoches County, evidences this type of Late Caddoan occupation (Allen Phase), possibly related to historically documented Hasinai Caddo in the southern part of theCaddo area (Story 1982). Within the immediate project area, the cultural taxonomic units for this time period are either the Angelina focus in the Angelina and Neches basins, or the Frankston focus in the upper Neches basin.

Historic Caddoan period (post-1680) sites are fewer in number (ca. 80-90) when compared to Late Caddoan/ProtohistoricPeriod sites. European materials at these sites include metal arrow points, buttons, gun parts, and other metal items. Directly 
associated temporally-diagnostic items of native manufacture for this time include Patton Engraved, Poyner Engraved, Natchitoches Engraved, and some Womack Engraved pottery (Perttula 1993b:149). Encroachment by Europeans and other native groups during the eighteenth century and decimation by European-introduced diseases resulted in the regrouping and consolidation of many of these groups, and this has been well documented archeologically and ethnohistorically (see Perttula 1992). Eventually they were removed from Texas altogether during the mid-nineteenth century.

\section{Previous Archeological Work in the Immediate Project Area}

An archeological survey for the existing paved trail system was completed in 1991 under Antiquities Permit No. 1004 (Corbin 1991) (see Figure 1). Fieldwork consisted of a cultural resources survey of 71.7 acres as part of the Phase I of park development, and employed a combination of pedestrian survey, shovel tests, and evaluations of existing impacts. No archeological sites were recorded within the limits of thissurvey and the proposed park project was recommended for "cultural resource clearance" (Corbin 1991:4). The State Historic Preservation Office concurred on June 11, 1991. A small area at the center of this tract remained unevaluated by this survey, and is the chosen location for the proposed trail. No previously recorded sites are located within the project area. However, reconnaissance indicated that areas along the proposed trail route might contain archeological materials, and that a survey was needed.

\section{ARCHEOLOGICALSURVEY OF PROPOSED TRAILS}

\section{Methodology}

Between December 17 and 18, 1998, TxDOT archeologist Steve Ahr, with the assistance of Jay Tullos, Lance Marshall, and Christine Crosby from the TxDOT Tyler District, performed an archeological survey along the proposed trail route. The length of the project area was first walked and the surface was inspected for archeological materials. However, ground visibility was generally poor. Shovel tests were then excavated along the wooded trail area, and cut bank exposures along the drainage and bare exposed ground surfaces were inspected. Shovel tests were spaced in approximately 40-m intervals along the entire proposed route. Each was approximately $30 \mathrm{~cm}$ in diameter and was manually excavated to one meter below surface, or until the clay horizon was encountered. All sediments were screened with 114-inch hardware cloth, and artifacts were collected and inventoried. Recovered artifacts were placed in bags and the depth was recorded along with provenience information. Shovel test depth, soil color, texture, integrity, and any anomalous observations were recorded in field books.

\section{Results}

Eighteen shovel tests were excavated along the trail route (see Figure 2). Shovel testing began at the northwest end of the project area near the west branch tributary of Mud Creek. Shovel tests I through 7, that followed the course of the creek, were placed along the forested edge approximately 10 meters from the creek bank. From Shovel Test 7 , shovel testing followed the proposed trail to the northeast. Shovel tests continued northeast, following the east branch until reaching the northeast end of the project area where it intersects with the paved northern trail. Several cutbank faces were examined along both branches to assess the character of the sediments and soils. Cutbank faces revealed relatively shallow sandy deposits overlying sterile clay subsoil. Shovel tests revealed one unrecorded site, 41SM231.

Shovel Test 10 was the initial positive shovel test and yielded a total of four aboriginal pottery sherds (Figure 3). Three were recovered from the upper $30 \mathrm{~cm}$ and one from approximately $90 \mathrm{~cm}$. As a result of this discovery, four additional shovel tests were excavated nearby to define site boundaries within the trail corridor. Shovel Test 10.1 yielded five sherds from between 15 and $60 \mathrm{~cm}$ below surface. Shovel Test 10.4 yielded two pottery fragments from the uppermost $5 \mathrm{~cm}$, and Shovel Tests 10.2 and 10.3 were negative. No other artifact 




Figure 3. 41SM 231 site map.

types (e.g., debitage or tools) were recovered from shovel tests. No evidence of features (historic or prehistoric) was identified.

Site boundaries within the area of potential effect were established on the basis of archeological materials from shovel tests. A shovel test at the west margin of the corridor was positive, and it is possible that the site continues beyond this edge. No archeological materials were found south of the initial positive shovel test. Based on this distribution within the area of potential effect, the site boundaries extend approximately 10 meters from east to west, and 10 meters from north to south. No other shovel tests along the proposed trail revealed cultural materials.

Due to the potential for temporally and/or functionally diagnostic ceramics, TxDOT conducted additional testing to determine if this portion of the site exhibited sufficient integrity to contribute to the site's eligibility for inclusion on the NRHP or warranted designation as a SAL.

\section{ARCHEOLOGICAL TESTING OF 41SM231}

\section{M ethodology}

Two contiguous 1-x-1-m test units were placed at the center of the site within the proposed pedestrian trail route (see Figure 3). Based on survey information, the site size within the trail corridor is approximately $100 \mathrm{~m}^{2}$. Excavation of two $1-x-1-m$ test units equates to two percent of the site within the corridor. Units were hand-excavated in arbitrary 10-cm levels by shovel skimming and troweling, and all sediments were screened with 114-inch hardware cloth. Informa- 
tion for each level was recorded on standardized level forms. When identified in situ, artifacts were mapped in the unit floor. All artifacts were collected, cleaned, provenienced, catalogued, and placed in bags. Test unit profiles, including soil color, texture, and any anomalous observations, were drawn and photographed.

\section{Results}

Test units revealed I-m thick sandy loam deposits over sandy clay subsoil (Figure 4). Excavation continued until the clayey Bt-horizon was encountered at $100 \mathrm{~cm}$ below surface. At this depth, soils became clayey and saturated with water. The upper ca. $25 \mathrm{~cm}$ of deposits consists of a loose, organic rich brown (10Y R 4/3 to 414) loamy sand Ahorizon. This horizon graduated into a more compacted yellowish brown (10Y R 4/6) and pale brown (10Y R 5/4) loose sand. Finally, a pale brown (1 OY R6/3) saturated E-horizon was encountered beginning at about $90 \mathrm{~cm}$ below surface. The sterile, sandy clay Bt-C horizons were at about $100 \mathrm{~cm}$. Krotovinas and roots were abundant throughout the upper $50 \mathrm{~cm}$, then decreased significantly below that level. Bioturbation was most evident in the upper half of the test units. Increased clay content was observed at about $80 \mathrm{~cm}$, while there was a slight increased in the number of gravels at about $60 \mathrm{~cm}$. A total of 120 artifacts, ninety-eight of which are aboriginal ceramics, were recovered from shovel tests and test units. Sixtyseven percent of the total artifacts were concentrated within the upper $30 \mathrm{~cm}$ of deposits, while $30 \%$ were distributed between $40-70 \mathrm{~cm}$. Distributing information for all recovered materials is presented in Table 2.

\section{Test Unit 1}

Test Unit 1 was excavated to $90 \mathrm{~cm}$ and yielded 38 ceramic sherds, one bifacially modified chert flake, and several large pieces of sandstone (Table 2). A majority of the ceramics $(\mathrm{N}=23)$ from this

\section{SM231}

\section{West Wall Profile}

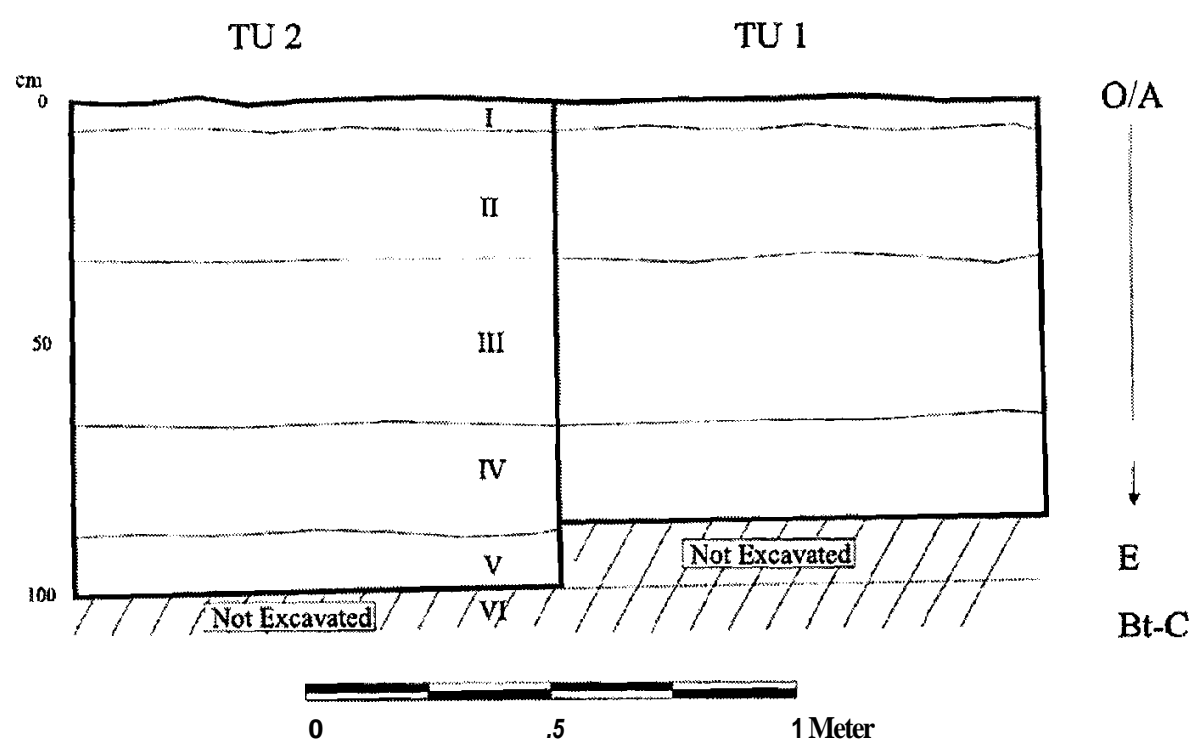

1. Leaf liner; rich organiaand roots; 0 -horizon.

II. 10YR4/30 414 brown loamy sand; numerous Krotovinas.

III. 10Y R 4/6compacted yellowish brownsand, increased gravel contentat $60 \mathrm{~cm}$.

IV $10 Y R 5 / 4$ loosepale brown sand; increased clay contentat $80 \mathrm{~cm}$.

V. 10YR6/3 pale brown; saturated E-horizon.

$\checkmark$ Sandy clay Bt-C horizons.

Figure 4. Test unit profiles. 
unit were recovered from Level 2. The number of ceramics recovered from below this level drops dramatically, and no materials were recovered below Level 5. Excavation continued through Level 9 and was terminated due to a lack of artifacts.

\section{Test Unit 2}

Test Unit 2 was excavated to $100 \mathrm{~cm}$ and yielded 49 ceramic sherds, one calcined bone from Level 2, two flakes from Level 3, and one flake from Level 10. Several large hematite sandstone pieces were also recovered. Ceramic distribution for Unit 2 was similar to Unit 1 in that most ceramics were found within the upper $30 \mathrm{~cm}$ (see Table 2). However, Level 5 produced the highest number of ceramics $(\mathrm{N}=12)$ from any one level. There is also another slight increase in number in Level $7(\mathrm{~N}=7)$. At $100 \mathrm{~cm}$, the unit floor became saturated. There was an overall general increase in clay beginning at about $80 \mathrm{~cm}$, and a corresponding decrease in artifact count. The unit was terminated at $100 \mathrm{~cm}$.

\section{Ceramic Descriptions}

Ninety-eight ceramic sherds were recovered from shovel tests and test units. Each sherd was analyzed for part of vessel, decoration technique, temper, and size. Major characteristics in the ceramic assemblage for each variable are discussed below. These data are also summarized in Table 3.

\section{$\underline{\text { Part of Vessel }}$}

Most pieces are extremely fragmented, and little could be determined for this variable. Nearly all sherds $(\mathrm{N}=84)$ consist of typologically unidentifiable body fragments averaging about $2 \mathrm{~cm}$ in diameter. Of these body fragments, 14 were brushed and three were incised. The remaining 67 exhibit no decoration. Nine rim sherds were also recovered. Six are plain. One appears to be Poyner Engraved, and dates to approximately AD 12001600 (Suhm and Jelks 1962). This sherd was recovered from Unit 2, Level 5. Two punctated rim

Table 2. Distribution of archeological materials by level.

\begin{tabular}{|l|l|r|r|r|r|r|r|r|r|r|r|r|}
\hline \multirow{2}{*}{ Unit } & \multirow{2}{*}{ Material } & \multicolumn{7}{|c|}{ Level (10-cm) } & \multirow{2}{*}{ Total } \\
\hline & & $\mathbf{1}$ & $\mathbf{2}$ & $\mathbf{3}$ & $\mathbf{4}$ & $\mathbf{5}$ & $\mathbf{6}$ & $\mathbf{7}$ & $\mathbf{8}$ & $\mathbf{9}$ & $\mathbf{1 0}$ & 1 \\
\hline $\mathbf{1}$ & Burned clay & $\mathbf{1}$ & & & & & & & & & & 38 \\
\hline $\mathbf{1}$ & Ceramic & 5 & 23 & 5 & 4 & 1 & & & & & & 1 \\
\hline $\mathbf{1}$ & Edge-mod & & & 1 & & & & & & & & 4 \\
\hline 1 & Ironstone & & 3 & & & 1 & & & & & & 5 \\
\hline 1 & Sandstone & 2 & 3 & & & & & & & & & 1 \\
\hline 1 & Wire & & 1 & & & & & & & & & 1 \\
\hline 2 & Bone & & 1 & & & & & & & & & 49 \\
\hline 2 & Ceramic & 5 & 11 & 8 & 1 & 12 & 2 & 7 & 2 & 1 & \\
\hline 2 & Debitage & & & 2 & & & & & & & 1 & 3 \\
\hline 2 & Ironstone & & & & & 1 & & & & & & 4 \\
\hline 2 & Sandstone & & & 2 & & 2 & & & & & & 4 \\
\hline ST 10 & Ceramic & & & 3 & & & & & & 1 & & 5 \\
\hline ST 10.1 & Ceramic & & 2 & & & 2 & 1 & & & & & 2 \\
\hline ST 10.4 & Ceramic & 2 & & & & & & & & & & 120 \\
\hline & Total & 15 & 44 & 21 & 5 & 19 & 3 & 8 & 2 & 2 & 1 & 1 \\
\hline
\end{tabular}




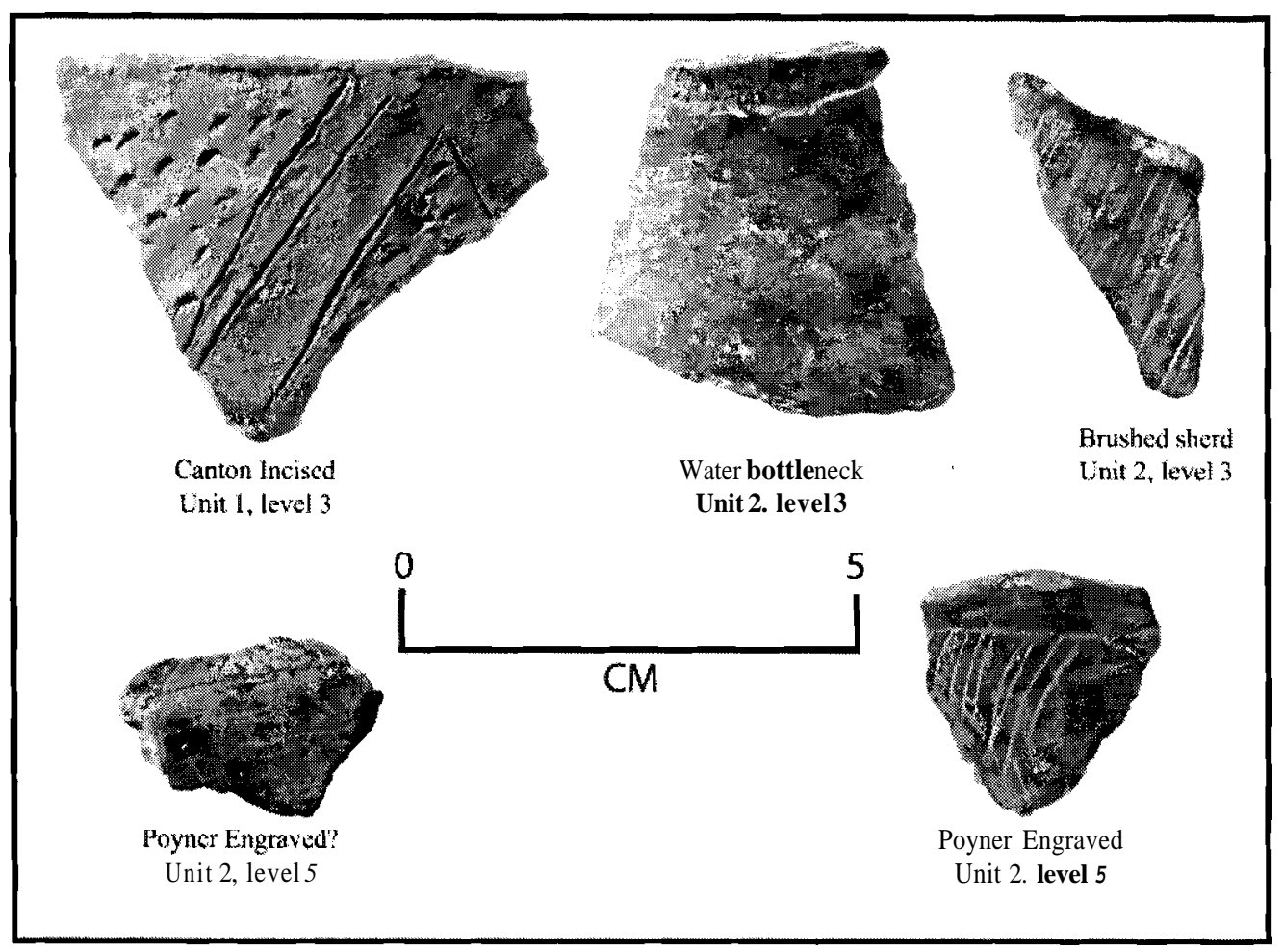

Figure 5. Selected ceramic sherds from 41SM 231.

sherds were also recovered. One from Unit 1, Level 2 is an everted rim with fingernail punctations. However, the sherd is too small to positively type. The second is from Unit 1, Level 3, and appears to be Canton incised (Figure 5). This type dates to approximately AD 1000 (Suhm and Jelks 1962). Two plain neck fragments were recovered from Levels 2 and 3 in Unit 2 and both appear to be fragments of a water bottle. One plain unidentifiable base fragment was recovered from level 5 in Shovel Test 10.1. Finally, two carinated fragments were recovered, both from Unit 2, Level 5. One is possibly a Poyner Engraved, although it is too fragmented to be absolutely positive. The second is plain. All identifiable vessel parts were located within the upper $50 \mathrm{~cm}$.

\section{Decoration Technique}

All sherds were examined for exterior decorations such as brushing $(\mathrm{N}=14)$, incising $(\mathrm{N}=3)$, punctations $(\mathrm{N}=2)$, and engraving $(\mathrm{N}=2)$. Most of the sherds $(\mathrm{N}=77)$ were plain and did not exhibit any decorations. Plain sherds dominate the assemblage and were concentrated in Level 2, below that their density steadily decreased. Similarly, brushed sherds are most common in this level $(\mathrm{N}=6)$, and in Level $7(\mathrm{~N}=3)$. As stated above, two Poyner Engraved and one Canton incised sherd were recovered (Figure 5). The Canton incised sherd is fairly large, and contains several punctations within small triangles and a series of parallel diagonal incisions terminating at the rim. One Poyner Engraved sherd contains a series of oval, concentric lines. There is little contrast between the surface and core colors within the engraving, and no evidence of red ocher in-filling was seen. The other Poyner Engraved is a fragment of a carination. It has an orange exterior, with red-filled lines (Figure 5). This sherd is very small and the assignment of the Poyner Engraved type is only tentative; however, considering another of the same type was found in the same unit and level, this may be a reasonable assertion. A few sherds (ca. 5\%) in the assemblage exhibit some sort of exterior or interior smoothing. 
Temper

Clean breaks on all sherds were examined under a microscope for temper composition. Sand temper was the most abundant observed $(\mathrm{N}=69)$. Other tempers consist of grog $(\mathrm{N}=20)$, bone $(\mathrm{N}=4)$, sand/bone $(\mathrm{N}=3)$, and bone/grog $(\mathrm{N}=2)$. Fifty-two percent of sand tempered sherds were concentrated in the upper $30 \mathrm{~cm}$. Grog tempered sherds peak at about $20 \mathrm{~cm}, 50 \mathrm{~cm}$, and between 60 and $80 \mathrm{~cm}$ below surface. All sherds with only bone temper are concentrated between 50 and $80 \mathrm{~cm}$ below surface, as well as all sherds with bone/grog, and nearly all sherds with sand/bone. The abundance of sand temper probably represents natural inclusions in the clay rather than something that was deliberately added. Sand temper comprises all rim and both neck fragments. One carination contains sand and the other grog, and the base fragment contains sand and bone temper.

Size

The longest sherd axis (diameter) and thickness of each sherd was recorded. Average thickness was $0.64 \mathrm{~cm}$, and average diameter was $2.13 \mathrm{~cm}$. In general, average sherd diameter increases with increased depth, and smaller sherds are concentrated in the upper $20 \mathrm{~cm}$. No sherds less than $2 \mathrm{~cm}$ in diameter were recovered below $50 \mathrm{~cm}$. Average sherd diameters in Levels 1-5 ranges are between 1.2 and $2.2 \mathrm{~cm}$, although Level 3 sherds average $2.6 \mathrm{~cm}$ in diameter. Sherd diameter averages in levels 6-9 are between 2.7 and $3.3 \mathrm{~cm}$. Average sherd thickness per level remains fairly consistent throughout all levels.

\section{Discussion}

Both test units revealed similar vertical artifact distributions, with most artifacts concentrated in the upper $20 \mathrm{~cm}$. In the field it was observed that most of the ceramics were coming from the lower portions of Level 1 and upper portion of Level 2. Other trends in the data indicated that overall, there is a general decrease in the density of ceramic materials with increasing depth, particularly below $50 \mathrm{~cm}$. There is also a general increase in sherd size with increasing depth (Figure 6). No sherds below $50 \mathrm{~cm}$ have a diameter less than 2 $\mathrm{cm}$, and $85 \%$ of sherds were recovered from the upper $50 \mathrm{~cm}$. Level 2 contains the most sherds, which are, on average, smaller than all other levels except Level 4. Sand- and grog- tempered pottery is the most common, and was distributed throughout most levels. Sand temper comprises most of the identifiable vessel parts. Except for three brushed sherds in Level 7, all decorated ceramics were located in the upper $50 \mathrm{~cm}$. Additionally, all identifiable vessel parts were recovered from the upper $50 \mathrm{~cm}$.

Only three sherds contained enough diagnostic features to allow typing. Two sherds appear to be Poyner Engraved, dating to around AD 1200-I 600, and were recovered from between $40-50 \mathrm{~cm}$. The other is Canton Incised, dating to around AD 1000 (Suhm and Jelks 1962), and was found at $25 \mathrm{~cm}$ below surface. The reverse stratigraphic position of these diagnostics is possibly one indicator of the extensive bioturbation in the upper $50 \mathrm{~cm}$. However, it is possible that these two types were contemporaneous at this site, particularly since Canton incised can post date AD 1000 (Suhm and Jelks 1962). In any event, the dates are based on old research and are not likely reliable enough to make such specific statements about when the site was occupied.

Interestingly, $50 \mathrm{~cm}$ below the modern surface appears to be a threshold point in terms of artifact size and number. Field observations indicate that bioturbation, and perhaps plowing and trampling, has reworked the upper deposits. For example, in addition to having the highest concentration of sherds, modern wire fragments were also recovered at $15 \mathrm{~cm}$ below the surface in Unit 1. Postdepositional processes might account for the larger number of sherds and the overall smaller size of sherds in the upper $50 \mathrm{~cm}$, and some combination of these factors has also moved larger pieces down the sandy profile. 
Table 3. Distribution of ceramic attributes by level.

\begin{tabular}{|c|c|c|c|c|c|c|c|c|c|c|}
\hline \multirow[b]{2}{*}{ Vessel Part } & \multicolumn{9}{|c|}{ Level (10-cm) } & \multirow{2}{*}{ Total } \\
\hline & 1 & 2 & 3 & 4 & 5 & 6 & 7 & 8 & 9 & \\
\hline Base & & & & & 1 & & & & & 1 \\
\hline Body & 11 & 32 & 13 & 4 & 10 & 3 & 7 & 2 & 2 & 84 \\
\hline Carination & & & & & 2 & & & & & 2 \\
\hline Neck & & 1 & 1 & & & & & & & 2 \\
\hline $\operatorname{Rim}$ & 1 & 3 & 2 & 1 & 2 & & & & & 9 \\
\hline Total & 12 & 36 & 16 & 5 & 15 & 3 & 7 & 2 & 2 & 98 \\
\hline \multirow{2}{*}{ Decoration } & \multicolumn{9}{|c|}{ Level $(10-\mathrm{cm})$} & \multirow{2}{*}{ Total } \\
\hline & 1 & 2 & 3 & 4 & 5 & 6 & 7 & 8 & 9 & \\
\hline Brushed & 1 & 6 & 2 & & 2 & & 3 & & & 14 \\
\hline Engraved & & & & & 2 & & & & & 2 \\
\hline Incised & 1 & & 2 & & & & & & & 3 \\
\hline Plain & 10 & 29 & 11 & 5 & 11 & 3 & 4 & 2 & 2 & 77 \\
\hline Punctated & & 1 & 1 & & & & & & & 2 \\
\hline Total & 12 & 36 & 16 & 5 & 15 & 3 & 7 & 2 & 2 & 98 \\
\hline \multirow{2}{*}{ Temper } & \multicolumn{9}{|c|}{ Level $(10-\mathrm{cm})$} & \multirow{2}{*}{ Total } \\
\hline & 1 & 2 & 3 & 4 & 5 & 6 & 7 & 8 & 9 & \\
\hline Sand & 9 & 30 & 12 & 5 & 8 & & 3 & & 2 & 69 \\
\hline Grog & 2 & 6 & 4 & & 4 & & 2 & 2 & & 20 \\
\hline Bone & & & & & 1. & 2 & 1 & & & 4 \\
\hline Sand/bone & 1 & & & & 1 & & 1 & & & 3 \\
\hline Bone/grog & & & & & 1. & 1 & & & & 2 \\
\hline Total & 12 & 36 & 16 & 5 & 15 & 3 & 7 & 2 & 2 & 98 \\
\hline
\end{tabular}

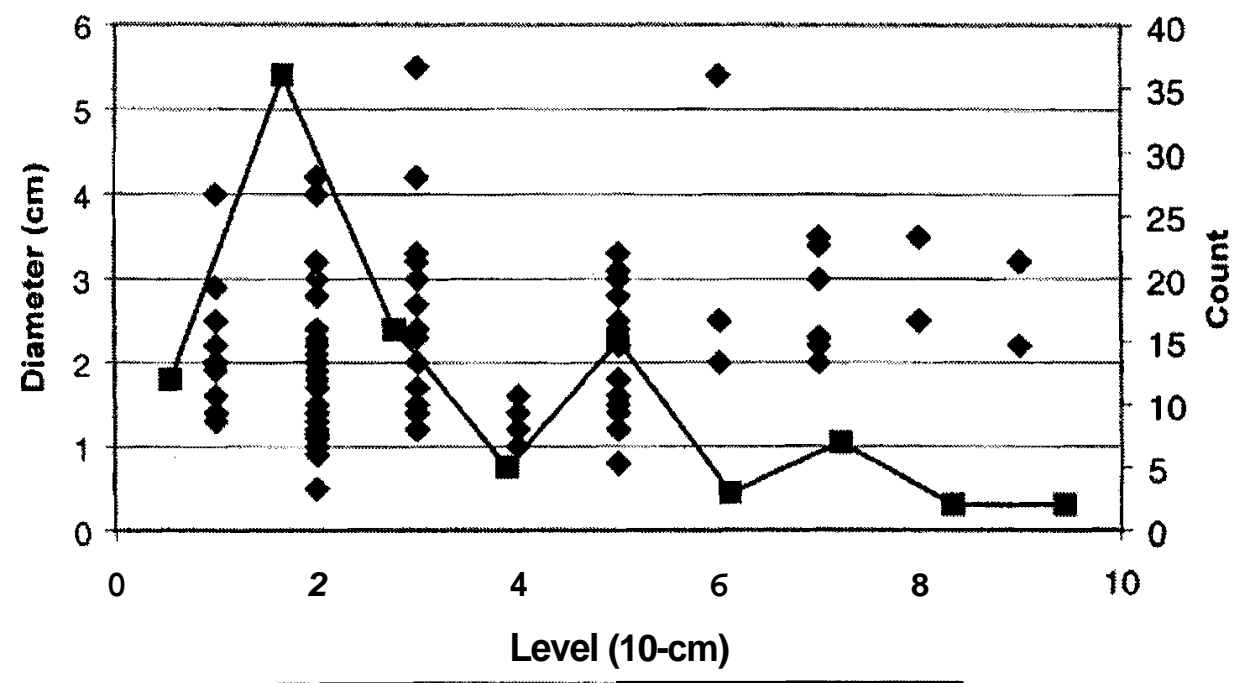

Number of Sherds $\quad$ Sherd Diameter

Figure 6. Ceramic sherd counts and size by level. 


\section{CONCLUSIONS AND RECOMMENDATIONS}

Eighteen shovel tests were excavated along the proposed trail route to locate buried archeological materials. Four additional shovel tests were used to delineate one previously undocumented site (41SM23 1), found buried throughout the upper meter of sandy deposits. Eleven ceramic sherds were recovered from site definition shovel tests. Two subsequent I-x-1-m test units excavated to ca. 1 meter below surface revealed an assemblage comprised almost entirely of small ceramic sherds $(\mathrm{N}=98)$. Most are less than $2 \mathrm{~cm}$ in diameter. Given the small number of sherds and their small size, it is unlikely that this assemblage could yield important new information.

A single edge-modified flake and a few pieces of debitage were the only lithic artifacts recovered. No burned rock features, feature stains, postmolds, or datable remains were identified. A few pieces of ironstone and sandstone fragments were observed; however, they only appeared to be natural inclusions weathered from underlying sandy bedrock, rather than the disarticulated remains of former fire-cracked rock features.

One Canton Incised and two Poyner Engraved sherds were recovered. Canton Incised is identified as a Sanders Focus type and has a wide distribution. largely due to trade. Similar incised types are known throughout the Caddoan area (see Suhm and Jelks 1962). According to Suhm and Jelks (1962) Poyner Engraved is diagnostic of the Frankston Focus, which is common from the Neches River headwaters to its confluence with the AngelinaRiver. Previous excavationsat nearby
Lake Palestine identified numerous sites attributable to the Late Caddoan Frankston Focus (Guy 1990:57). Recovered diagnostics from 4 1SM23 1 suggest that the site was occupied somewhere within the Early to Late Caddoan Periods between AD 1000 and 1600. However, Poyner Engraved has also been related to Historic Caddoan period (post-1680) sites that contain European materials, suggesting the site might have been occupied at some point by later groups.

Based on field observations and the nature and distribution of the artifact assemblage, the upper deposits appear to have been impacted and reworked by a variety of site formation processes. As a result, most of the ceramics have been broken to a point beyond our ability to gain useful information about the native inhabitants of this region. The small quantity of recovered materials, the lack of features, and the largely non-diagnostic character of the assemblage limit the amount of information that can be derived.

Based on these investigations the portion of site 41SM231 within the trail corridor does not retain sufficient integrity nor is it likely to yield important information that would make it eligible for inclusion in the NRHP or merit designation as a SAL. Therefore, the proposed trail should have no effect on archeological historic properties or SALs, and no further archeological work is recommended for the proposed trail corridor. However, because the site may extend beyond the examined corridor, future development activity adjacent to the trail may require examination to determine whether intact archeological deposits are present. 


\section{REFERENCES CITED}

Anderson, K.M.

1972 Prehistoric Settlement of the Upper Neches River. Bulletin of the Texas Archeological Society 43:121-197.

Anderson, K.M., K. Gilmore, O.F. McCormick III, and E.P. Morenon

1974 Archeological Investigations at Lake Palestine, Texas. Contributions in Anthropology 11. Southern Methodist University, Dallas.

Barnes, V.E

1967 Geologic Atlas of Texas, Tvler Sheet. Bureau of Economic Geology, University of Texas at Austin.

Blair, W.F.

1950 The Biotic Provinces of Texas. The Texas.Journal of Science 2(1):93-116.

Corbin, J.E.

1991 Archeological Survey of the Tyler South Greenbelt Park in the City of Tyler, Smith County, Texas. Archeological Survey Report No. 91-14 submitted to the City of Tyler. Antiquities Permit No. 1004.

Fenneman, N.M

1931 Physiography of the Western United States. McGraw-Hill, N ew York.

Fields, R.C., S.A. Tomka, and T.K. Perttula

1993 Hunter-Gatherer Mobility in Northeast Texas. In Archeology in the Eastern Planning Region, Texas: A Planning D ocument,edited by N.A. Kenmotsu and T.K. Perttula, pp. 69-96. Cultural Resources Management Report No. 3. Department of A ntiquities Protection, Texas Historical Commission, Austin.

Gilrnore, K.

1983 Caddoan Interaction in the Neches Valley, Texas. Reprints in Anthropology 27. J \& L Reprint Company, Lincoln.

Gould, F.W.

1975 Texas Plants: A Checklist and Ecological Summary. The Texas A\&M University System, Texas Agricultural Experiment Station, College Station.

Guy, J.

1990 Previous Archeological Investigations. In The Archeologyand Bioarcheology of the West Gulf Coastal Plain: Volume I, by D.A. Story, J.A. Guy, B.A. Burnett, M.D. Freeman, J.C. Rose, D.G. Steele, B.W. Olive, and K.J. Reinhard, pp. 27-130. Research Series No. 38, Arkansas Archeological Survey, Fayetteville. 
Hatherly, D.T.

1993 Soil Survey of Smith C ounty,Texas. United States Department of Agriculture, Natural Resources Conservation Service, in cooperation with the Texas Agricultural Experiment Station and the Texas State Soil and Water Conservation Board.

Johnson, L.

1961 An Archeological Survey of Blackburn Crossing Reservoir on the Upper Neches River. Bulletinof the Texas Archeological Society 31:213-238.

Perttula, T.K.

1988 The Hurricane Hill Site (41HP106): Excavations at an Early Ceramic Caddoan Settlement at Cooper Lake, Hopkins County,Texas. Contributions No. 9, Institute of Applied Sciences, University of North Texas, Denton.

1992 The Caddo Nation: Archaeological and Ethnohistorical Perspectives. University of Texas Press, Austin.

1993a The Development of agriculture in Northeast Texas Before AD 1600. In Archeology in the Eustern Planning Region, Texas: A Planning Document. Cultural Resources Management Report No. 3., edited by N.A. Kenmotsu and T.K. Perttula, pp. 121-146. Department of Antiquities Protection, Texas Historical Commission, Austin.

1993b Effects of European Contact on Native and lmmigrant Indians in Northeast Texas. In Archeology in the Eastern Planning Region, Texas: A Planning Document. Cultural Resources M anagement Report No. 3., edited by N.A. Kenmotsu and T.K. Perttula, pp. 147-187. Department of Antiquities Protection, Texas Historical Commission, Austin.

Perttula, T.K., and J.E. Bruseth

1998 The Native History of the Caddo and Their Place in Southeastern Archeology and Ethnohistory. Studies in Archeology 30. Texas Archeological Research Laboratory, The University of Texas at Austin.

Perttula, T.K., and N.A. Kenmotsu

1993 Introduction. In Archeology in the Eastern Planning Region, Texas: A Planning Document. Cultural Resources Management Report No. 3., edited by N.A. Kenmotsu and T.K. Perttula, pp. 35-47. Department of Antiquities Protection, Texas Historical Commission, Austin.

Perttula, T.K., R.C. Fields, J.E. Corbin, and N.A. Kenmotsu

1993 The Emergence of Sedentism in Northeast Texas, ca. 500 BC to AD 1000. In Archeology in the Eastern Planning Region, Texas: A Planning Document. Cultural Resources Management Report No. 3., edited by N.A. Kenmotsu and T.K. Perttula, pp. 97-120. Department of Antiquities Protection, Texas Historical Commission, Austin.

Shafer, H.J.

1981 Archeological Investigations at the Attaway Site, Henderson County, Texas. Bulletin of the Texas Archeological Society 52:147-178. 
Story, D.A.

1965 The Archeology of Cedar Creek Reservoir, Henderson and Kaufman Counties, Texas.

Bulletin of the Texas Archeological Society 36:163-257.

1990 Cultural History of the Native Americans. 111 The Archeology and Bioarcheology of the Gulf Coastal Plain: Volunie I, by D.A. Story, J.A. Guy, B.A. Burnett, M.D. Freeman, J.C. Rose, D.G. Steele, B.W. Olive, and K.J. Reinhard, pp. 163-366. Research Series No. 38. Arkansas Archeological Survey, Fayetteville.

1997 1968-1970 Archeological Investigations at the George C. Davis Site, Cherokee County, Texas. Bulletin of the Texas Archeological Society 68:1-113.

Story, D.A. (editor)

1982 The Deshazo Site, Nacogdoches County, Texas, Volunie I: The Site, its Setting, Investigation, Cultural Features, Artifacts of Non-Native Manufacture, and Subsistence Remains. Texas Antiquities Permit Series, No. 7, Texas Antiquities Committee.

Suhm, D.A., and E.B. Jelks (editors)

1962 Handbook of Texas Archeology: Type Descriptions. The Texas Archeological Society Special Publication No. 1, and the Texas Memorial Museum, Bulletin No. 4. Austin.

Thunnond, P. J.

1990 Archeology of the Cypress Creek Drainage Basin, Northeastern Texas and Northwestern Louisiana. Studies in Archeology 5, Texas Archeological Research Laboratory, The University of Texas at Austin. 